\title{
Building on Unsafe Foundations? International Law making and the EU
}

\author{
Dr W. John Hopkins \\ Senior Lecturer, School of Law, University of Canterbury
}

\section{Introduction}

A major driver of the European Union's current reform process has been the need to create systems that enable the EU to participate more effectively in the field of international relations. Part of the reason for this involves the EC's growing role in international governance. One aspect of this that is particular interest, is the EU's developing role in international organisations, specifically the WTO. ${ }^{1}$ Such developments are based upon the assumption that greater EU involvement in external affairs is a positive development. This paper questions this assumption and in particular examines the difficulties inherent in holding EU activities in international law to account. More specifically it examines whether the EU's involvement in international organisations can be regarded as legitimate given its current accountability structures.

These problems are not unique to the EU, however, and the increasingly complex world of international institutions presents a key challenge for domestic public law. International governance, with few exceptions, sees an expanded de facto legislative role for domestic executives and traditional constitutional accountability mechanisms (often through executive responsibility to Parliament) are often inadequate. This has lead to significant debate in the domestic academic literature on the suitability of such mechanisms and a search for new avenues of accountability. ${ }^{2}$ However, despite such debates becoming relatively commonplace in relation to domestic government, they have largely been absent from discussion of the EU's growing involvement in international law making generally and international organisations in particular. ${ }^{3}$ This paper aims to make a small contribution to filling this lacuna by considering the accountability problems that face the EU in this arena and examining whether the current European "constitutional" mechanisms are sufficient to ensure legitimate and accountable EU involvement in international law making. It concludes by suggesting that the EU is in danger of buying into the "club" model of international governance with severe implication for the legitimacy of European external affairs. Perhaps, more importantly, it suggests that the combination of international practice and the internal mechanisms of the EU may make such accountability almost impossible to achieve without structural change at the international level itself.

\section{External Relations and Accountability}

The accountability of national executives in their relations with other states has always posed difficult questions for domestic constitutional law. The problem is a simple one. While domestically, the constitution may provide a variety of accountability mechanisms; checks and balances or fora for the discussion of public decisions, at the international level such mechanisms are rare. Instead, the traditional model of international relations sees states interacting as psuedo-individuals in a contractual relationship with each other. To this we can overlay the concepts of Custom and the increasingly importance of Jus Cogens but in essence the contractual model, through the medium of

1 The EU has formal representation in only two international Organisation, the WTO and the UN FAO. Its informal role extends far beyond this, however.

2 See Harden \& Lewis, The Noble Lie, Hutchinson, 1986; Adam Tomkins, Public Law, Clarendon, 2003

3 Exceptions Lord 
treaty making remains the dominant approach to international law making. As in all contractual relationships, the key element is acceptance of the agreement by the two parties. International law decrees that acceptance and how it is achieved is a matter of domestic constitutions. ${ }^{4}$ By such means accountability is introduced as, at least in democratic societies, the agreement must gain the approval of the electorate, or more likely their representatives. The method by which it is decreed to have occurred is left to the national system. International law does not concern itself with these niceties of domestic law. It concerns itself only with the fact that that states have accepted the international obligation. How they do so and the democratic credentials of such an acceptance is not the concern of international lawyers. It is the underlying premise of this paper that it should be.

The reasons for the disconnection between international law and public law can be traced back to the early development of the former. The very basic elements of international law were developed as a response to the new European order created by the development of the Westphalian State. The crumbling of the quasi-feudal monarchical system in the Seventeenth Century meant that alternative models of "international" governance needed to be established. Nature abhors a vacuum and it was into this space that the elements of what we now called international law poured. In the late Seventeenth Century, democracy was, of course, in its infancy. As a result the international law regime developed during this period had no place in it for the sort of accountability arguments that are the focus of this paper. International law was about states accepting their responsibilities on the international stage. The realities of such relations meant that states would be represented by their executives, whoever they may be.

This executive dominated model has largely survived into modern times despite the rise of democratic systems, particularly in post-war period. The reasons are twofold. Firstly, the practicalities of negotiations mean that a representative of the state, in the form of the executive, must conduct the actual discussions. Secondly, until recently, the issues being discussed were largely in the hands of the executive branch anyway. International relations was the game of states concerned largely with war, peace and international diplomacy. International law thus continued to raise few concerns about accountability.

The world has changed, however, and whether we like it or not, so has the nature of international law. Now the watchword is not law but "governance" as international law and international institutions reach deep down into national systems of regulation. This poses a significant problem for national constitutions and their accountability mechanisms. Although in many states a national parliament may have the ability to veto an international treaty, or agreement, in practice this power is of limited use. International affairs by their very nature are conducted in secrecy and the national Parliament, if it is involved at all, will be wheeled out to approve the text, by which time the negotiations are already done and dusted. ${ }^{5}$ The Constitutional mechanisms of the nation-state are this bypassed leading to a de facto empowerment of the executive branch.

The position of the domestic constitutional structures are further weakened by the development of international institutions and the creation of secondary international "law". In these cases, once approval is given by the national Parliament (if it is required), then decision making passes to an international body where the executive will represent the national interests. The executive may be held accountable for such decisions at the ballot box or through the representative assembly, but in practice the secrecy that surrounds such international discussions makes meaningful discussion of the national position difficult if not impossible. Most legislative involvement is once again post facto and even if the executive is required to justify its actions in relation to external relations, it is often not in its interests to be entirely honest. As Howse has commented, although the national executives may be need to account for their actions in relation to a particular international agreement and their own role in the negotiations, independent verification is extremely hard to

4 Vienna Convention on the Law of Treaties, Article ***

5 The United States is a classic example of this, whereby the significant power of Congress is nullified by its exclusion from the process, except as a wrecking ball at the end of the ratification process. 
come by. ${ }^{6}$ In practice, international governance, for all its advantages in dealing with global issues, empowers the executive branch at the domestic level. ${ }^{7}$

\section{Federalism and International Law}

The complex nature of the European Union overlays and additional set of problems over this complex constitutional question. It will not have escaped the reader's attention that many of the constitutional problems raised above in relation to international governance and international institutions are exactly the arguments raised against the European Union and its "democratic deficit”. When the EU's internal democratic problems are added to those of the international governance arena, the position becomes significantly worse. The EU already struggles to claim legitimacy for its actions such are the limits of the internal accountability mechanisms. As the EU develops is external affairs responsibilities the accountability mechanisms get ever more strained. This makes the legitimacy of EU involvement in international regulation ever more questionable and allows for further erosion of already weak accountability mechanisms. It would be wrong to paint the EU as the villain here. In fact, the real problems lie in the complex political compromises that are such a feature of the EU's institutional structure. These merely amplify the problems of international governance already discussed above.

It is the submission of this paper that to make sense of this we must dispense with traditional "club" notions of international relations and instead turn to a different theoretical framework both to understand and perhaps solve some of the accountability issues that dog international regulation. This alternative requires use of the "f" word. Use of the term federalism, for reasons that elude this author, has consistently posed a problem for the EU. Discussion of international regulation from a federalist standpoint similarly causes a sharp intake of breath from traditional international lawyers perhaps with visions of global government conspiracy theorists. This failure to turn to federal theory is surprising and unfortunate as it submitted here that it is only by applying a federalist overlay that international governance (and the EU's role within it), can be understood.

Federalism, according to the work of Elazar and Watts is a political concept not a specific form of government. ${ }^{8}$ It can occur in many forms and exhibit many characteristics but one cannot define the world into federal and non-federal states. Instead, in contrast to the influential British writer, K.C. Wheare, federalism should be seen as a spectrum, with most states sitting somewhere on it. ${ }^{9}$ If one applies this approach, debates about whether the EU is a federal entity are largely meaningless as the EU is towards the federal end of the spectrum. More importantly, for this discussion, if we consider the development of international regulation and institutions as a system, then this "system" (or elements of it) also finds themselves placed towards the federal end of the spectrum. By taking this approach the issues facing the accountability of international regulation and the EU's involvement in it become much clearer.

Federalism presupposes a division of authority between levels of government. When federal units involve themselves in decisions which stay within their competencies, then accountability works relatively well. There may be some confusion over who does what but this is an unavoidable fact of life unless we have a totally unitary structure. In reality such a neat division does not occur and instead governments must negotiate and compromise to pursue their policies. Rarely will an activity be taken by one level which does not impact upon another. The essence of federalism is such

6 Robert Howse, "How to Begin to Think About the Democratic Deficit at the WTO” in Stefan Griller, ed., International Economic Governance and the Non-Economic Concerns: New Challenges for the International Legal Order, Springer-Verlag, New York, 2003

7 Within the European Union a similar issues arises with regional governments having their positions represented by their Member State. For this reason many regions place great emphasis on gaining a physical presence in the Council and other Member State delegations (e.g. the German Lander and the Scottish Executive).

8 See Ron Watts, Comparing Federal Systems ( $2^{\text {nd }}$ ed), McGill - Queens University Press, 2003. Daniel Elazar, Exploring Federalism, University of Alabama Press, 1987

9 Kenneth Wheare, Federal Government, OUP, Oxford, 1963 
compromises. $^{10}$

Federal theory has long recognised the accountability problems that this phenomenon creates. In effect when two levels of government co-operate they enter a decision making space that is no longer within the control of either the national or the state accountability mechanisms. Many have attempted to address by institutional or structural means. A second chamber to represent regional interests is not uncommon, although such an institution can create its own problems. In any event the key to successful accountability is ensuring that the decisions when reached are held accountability to a body representing the population as a whole. The same problem occurs at the international level.

\section{International Law and International Governance}

International Governance is an increasingly important part of the modern world. The idea of interconnected networks undertaking a governance role, outside the traditional structures of government is not a new one. ${ }^{11}$ The concept intersects with the European Union's development on two levels. Firstly, the EU is itself a product of international governance as Member States have pooled sovereignty to create new governance institutions which do not accord with the traditional models seen in the states themselves. In particular, legislative power is held primarily by anindirectly elected entity (the Council) while the Executive (the Commission) remains un-elected. The Commission has not been slow to recognise that the EU is a new form of "governance" and was a key reason why the term has grown in prominence. However, its use of the concept has been one-sided and an attempt to justify current practices rather than dealing with new factors. ${ }^{12}$

The EU's relevance to international governance does not stop at Europe's borders, however. The development of international regulation and law has necessitated its increased involvement in so called "external" affairs, most obviously in the field of international trade. There are two reasons for this, both pragmatic in nature. Firstly, the fact that the EU (particularly the EC pillar) has exclusive competence over areas in which international governance has developed (again, Trade is the classic, but not the only, example) means that the EU as an entity must be involved in such developments. Secondly, the economic strength of the EU 27 in global negotiations is such that all member states, and particularly those outside the big four, benefit from a collective approach. These pragmatic drivers, are nevertheless strongly tempered by the traditional desire of the Member States to retain sovereignty over foreign affairs. The problem, of course, and again the federal analogy is apposite, is that such a clear distinction between foreign and domestic is no longer tenable is large areas of policy.

The result of these competing desires of the Member States is a constant tussle between these opposing forces. The result is a series of pragmatic compromises and arrangements which allow the EU to function as an international actor, with limited capacity, while the states retain the ability to operate independently, at least in theory. Such mixity is the key to most EU external affairs at the present time and is particularly marked in its relations within international institutions. This fluid situation and dominance of "mixity" leads to significant complexity and confusion and seriously limits the ability of the EU to function at the international level.

The limits of EU action on the international stage has been examined in some detail elsewhere and indeed has been the subject of other papers at this conference. However, efficiency and effectiveness are not the only casualties from this constant skirmishing. The pragmatic and political nature of the developing external role of the EU means that constitutional matters, particularly

10 This is often described as co-operative federalism however although some systems are more co-operative than others in practice, all display elements of this approach.

11 See the work of Rod Rhodes and Gary Marks, amongst others

12 Chris Shore, Government without Statehood? Anthropological Perspectives on Governance and Sovereignty in the European Union, European Law Journal, Vol. 12, No. 6, pp. 709-724, November 2006 
accountability and legitimacy, are rarely discussed. This lacuna is potentially far more serious to the future of the EU than the concerns about the effectiveness of EU foreign policy. Ineffective EU foreign policy is unfortunate but can be remedied by other means. Unaccountable international governance on the other hand has the potential to fatally undermine democracy in the EU. This paper focusses on this unsung casualty and considers the accountability of the EU's involvement in international governance beyond its borders. How can the needs of international governance and the EU's involvement in it be squared with democratic accountability and legitimacy?

\section{International Regulation and the European Parliament}

The European Parliament is better placed than most legislatures to monitor and critique the external relations of the European Union's executive. Unlike most European legislatures it was designed as a deliberative body, charged with holding the executive to account. This is in contrast to most legislatures which, as the name suggests, were designed to pass legislation. The nature of modern governance means that this role is no longer the prime activity of representative assemblies, but most domestic assemblies have struggled with the shift, designed as they are to perform the legislative function. The European Parliament, in contrast, was designed from the start as a consultative and deliberative assembly and is thus far better equipped to undertake the scrutiny role, so vital for democratic accountability in the modern world. The potential for the European Parliament to perform an effective role may to some extent explain why the other institutions have been so reticent to give it a formal role. Instead the Parliament has had to make do and mend with a limited collection of accountability tools.

The formal powers of the European Parliament are limited to assent in a few limited and quasiconstitutional areas, namely Association agreements, institutional framework treaties as well as the amendment of legislation made under the co-decision procedure and control of the budget. The inter-parliamentary delegations (of which there are 40) are often seen as another method that the EP can utilise to involve themselves in the external affairs of the Union, by raising awareness of issues with fellow of Parliamentarians in partner states. However, the utility of these informal contacts is questionable at best and the uncharitable might see these relationships as more about international travel than international law making. It is clear that none of these methods provides an effective tool for controlling European policy. Indeed, it is the submission of this paper that the prevalence of mixity means that it is unlikely that they ever could.

The assent procedure is in theory a significant check on the powers of the Commissions and the Member States acting through the Council. In practice, the procedure is far too blunt an instrument to be effective. This is an issue, common to most domestic systems and is the reason that although a number of federal state systems give significant opportunity for the sub-state level to veto a treaty agreed by the state, few ever do so.

In the European system the problems are compounded by the fact that the European Parliament is consulted neither prior to the agreement being made nor after the original agreement has been approved. The latter is particularly significant in relation to International Organisation and their subsequent actions. In effect the involvement of the European Parliament involvement is at once both too early and too late. European Parliamentary involvement is too late due to the nuclear option that the assent process provides. The Parliament can throw out the agreement by its refusal to assent, but to do so will lead to the abandonment of the treaty as a whole. In relation to multi-lateral treaties this could lead to a carefully constructed compromise being thrown on the scrapheap and even in bi-lateral agreements, the final agreement is likely to represent a complex bargain. Rejection of one part will cause the whole to be rejected. Only when the issues at stake are fundamental, is such an outcome really credible. ${ }^{13}$

13 The Commission in particular is well aware of this and has used this to its advantage in relation to overcoming both Member State and Parliamentary opposition to elements of negotiated treaties. 
The assent procedure is also too early when the agreement concerns an international institution or a quasi-autonomous international agency created to support the work of an international treaty. ${ }^{14}$ In either case, the institution created by the agreement be in a position de facto or de jure to develop or create additions to the agreement. This institution, once created or accepted by the EU will no longer have a capacity of being controlled by the European Parliament. More, importantly given that international negotiations even within international institutions are usually undertaken behind closed doors (or if we use the WTO as an example by a small group of states, behind closed doors) specifically, any European Union input will be undertaken by the Commission and/or member States without further reference to Parliament. The assent process is therefore largely a case of buying a pig in a poke - when Parliament assents, it doesn't really know what it is agreeing to.

The European Parliament has worked hard to increase its role in external affairs and now has interinstitutional agreements to guarantee consultation. However, these powers are very limited and generic. The European Parliament's primarily method of holding the activities of the EU to account is through its Committee on Foreign Affairs. Three sub-committees sit in the fields of Human Rights, Security and Defence and Constitutional Affairs. This structure has been established to maximise the role of the Parliament in external relations. but the limited powers of the Parliament means that this Committee's influence is limited. The ability of the Parliament to scrutinise foreign affairs is limited by the ability of the Council and the Commission to refuse to respond to Parliamentary questions. The inter-institutional agreements, for example, which govern Parliament's role in the CFSP are limited in their practical effectiveness as Council fails to provide timely information to the Parliament. ${ }^{15}$

Perhaps most importantly, in the field of Common Commercial Policy, where the Parliament has a co-decision role in terms of EU legislation, co-decision does not extends to the external CCP. Even the approval of European CCP legislation as a result of external commitments is not subject to codecision. It is only when the Commission proposes the amendment of existing co-decision procedures that the European Parliament retains its co-decision powers.

Perhaps it is for this reason that the Parliament has not been slow to utilise its budgetary powers in the field of external relations. Both the Budget Committee and the Budget Control Committee have proved a relatively effective way of leverage concessions from both the Council and the Commission. However, although this policy has achieved some success in doing this but the practice has been highly controversial, with the Council in particular viewing this policy as an abuse of powers.

The potential for Parliamentary power in this area comes from the fact that external relations is a non-compulsory expenditure item. As such Parliament must approve such expenditure and may veto it. ${ }^{16}$ This has proved to be a useful lever and of far more utility that the formal role accorded to Parliament in the assent procedure. It was used particularly effectively in 1994 and led to the establishment of the European Initiative for Democracy and Human Rights under pressure from the EP. The strategy of the Parliament is two pronged, however, as it has been extremely vigilant in ensuring the Council in particular does not engage in action without the correct financial base being improved. This approach complements the strategy of using its budgetary power over external affairs and ensures that the European Parliament cannot be circumvented. ${ }^{17}$ The use of the budgetary power by the Parliament has ensured that funding of external affairs has become a key area of conflict between the European Parliament and the Council battles.

\footnotetext{
14 The latter model is an increasingly common approach

15 Inter-institituional agreement reference

16 After Lisbon the distinction will no longer exist.

17 Maurer, Andreas and Kietz, Daniela and Volkel, Christian, "Interinstitutional Agreements in the CFSP:

Parliamentarisation through the Backdoor?" European Union Studies Association Conference, 2005, 2005, pages 18, Austin, Texas
} 


\section{Conclusion - The Limits of the European Parliament in International Governance}

There is no doubt that the involvement of the European Parliament in external affairs has significantly widened debate and discussion of external affairs in the European Union and most significantly raised the profile of Human Rights and democracy issues on the EU's external policy agenda. It is on these issues that Parliamentary has clearly decided to focus, largely because they are areas upon which the whole Parliament can largely agree. By focussing on these specific issues. This focus has delivered a number of Parliamentary initiatives (such as the Sahkarov prize and the sub-Committee on Human Rights) as well as a number of programme negotiated with the wider European institutions (the European Intitiative for Democracy Human Rights, for example). They have not delivered specific policy changes in the EU nor allowed closer scrutiny of EU involvement in international institituions. The impact of the European Parliament remains minimal for three reasons.

Firstly, there is the traditional secrecy that is accorded to international relations. Although the Parliament can, at its request have a delegate present during EU Commission negotiations, there is little that the delegate can actually achieve. Secondly, the practicality of external relations means that decisions are often taken outside the formal processes and Parliament's role is restricted to the formal. Finally, and most crucially, the number of actors involved in establishing a foreign relations position, means that there is no single point of accountability for the Parliament to focus on. If this were not enough, the fact that the position of the EU when it enters into discussions at the international level, will be the subject of significant negotiations, leads us back to the federal problem we began with. No matter how effective the internal European mechanisms of accountability and at present they leave much to be desired, they will always fail to address accountability at the International level. This requires institutions of accountability be established at the global level.

The irony of this situation is that the European Parliament owes its existence to such a pragmatic development. It was not and is not a much loved institution and its role is clearly not that of representing the identity of the EU's citizens. It is a practical and generally effective tool in holding the necessary and again rather unloved European Union institutions to account. It is a classic example of representative and deliberative democracy, providing crucial illumination of the EU's external affairs. Perhaps the depressing conclusion, given that it is unlikely it will occur any time soon, is that only when the European Parliament's example is followed at the international level will the accountability problems that dog the EU in its external relationships be resolved. ${ }^{18}$

18 Luis Caberra, “The Inconveniences of Transnational Democracy” Ethics \& International Affairs, Volume 21 Issue 2, Pages 219 - 238 